\title{
圧電秦子応用微量液送ポンプの基礎検討*
}

\author{
小島吉 夫*1, 奥 沢 務*1, 坪内邦 良*1 \\ 高木勇輔*2, 浜野亘男*2
}

\section{Fundamental Investigation of Piezo-Element-Driven Pump Feeding a Trace of Liquid}

Yoshio KOJIMA, Tsutomu OKUSAWA, Kuniyoshi TSUBOUCHI, Yuusuke TAKAGI and Nobuo HAMANO

\begin{abstract}
Generally, a peristaltic pump and a syringe pump have been used to feed about $2(\mathrm{ml} / \mathrm{min}$ ) of liquid. But, as neither a continuous flow nor a low fluctuation flow can be realized simultaneously, a new type of microquantity pump is required in the field of pharmaceutic manufacturing. Therefore piezo-elements were applied to make a 2-dimensional pump suitable for multichannel and multistage pumps. The experiments have revealed that the pump successfully works and its head reaches a maximum of $18(\mathrm{kPa})$.
\end{abstract}

Key Words: Pump, Fluid Machinery, Piezo-Element, Check Valve

\section{1. 緒}

医療および製薬の分野では，数 $\mathrm{ml}$ 以下の薬液など の液送処理が必要である。特に, 分離分析用の機器の 一つである無担体電気泳動装置では, 50 チャンネル以 上の生体試料を高精度で移送するポンプが要求され る.従来この程の微至波送ポンプには, ペリスタポン プとシリンジポンプの 2 種類が多く用いられてきた。 このうち, ペリスタポンプは, 数個のローラによって チューブをしごくことで内部の液体を移送する方式で ある.このため, 連続供給が可能であるものの, 脈動 率(1) およびチューフ寿命の問題が大きい.一方, シリ ンジポンプはシリンジ(注射筒)をポンプとして使用す るもので, 低脈動で供給できるという特徵をもつ。し かし, シリンジポンプは夜の排出と供給を交互に行う 方式のため，二連化しなければ連続供給できないこと や多チャンネル化に対応しにくいという課題がある. そこで, 多チャンネル化に対応しやすく, 連続低脈動

* 平成 3 年 10 月 17 日 第 69 期全国大会愦演会において請 演，原稿受付 平成 4 年 5 月 20 日.

*1 正員，(株)日立製作所機械研究所（18317 日立市幸町 3-11).

*2 正员，(株) 日立製作所宇宙技術推進本部（-8101 東京都千 代田区神田騂河台 4-6).
供給が可能なポンプとして, バイモルフ型の圧電素子 をアクチュエータに利用した微量液送ポンプを開発(2) した。これまでに圧電素子をポンプに応用した研究に ついて数例(3)(4) 報告されているが, 本微量液送ポンプ は，積層化による多チャンネル化，および多段化によ る吐出圧向上に対応しやすい八ード構造に特徵があ る. 本報では，試作した単段 1 連モデルおよび 3 段 1 連モデルの基本特性を実験的に研究した結果について 報告する。

\section{2. 钎 号}

$D:$ 圧電素子の有効直径

$V:$ 電圧

$Q:$ 流量

$U:$ 圧電素子の変位量

$d_{31}:$ 等価圧電定数

$f:$ 圧電素子の駆動周波数

$h:$ 球冠の高さ

$k:$ 係数

$n:$ 压電素子数

$r:$ 球の半径

$t:$ 圧電素子の厚さ

$\varepsilon:$ 滞流係数 


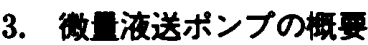

$3 \cdot 1$ 微量流送ポンプの㩐造図 1 に微量液送ポ ンプの構造例を示す．図は 3 段 3 連モデルの場合を示 したもので，ポンプ段数は流れの方向に沿って 1 段，2 段，3段とし，多段化することで吐出圧の增加を図れ る構造とした。本ポンプ 1 連 (3 段) 当たりの外形寸法 は，長さ $50 \mathrm{~mm} \times$ 幅 $20 \mathrm{~mm} \times$ 厚さ $3.5 \mathrm{~mm}$ である. 流 路部には流入側, 流出側とも外径 $1 \mathrm{~mm}$, 内径 0.7 $\mathrm{mm}$ のストレート管を取付け，流出側には $0.3 \mathrm{~mm} の$ ノスルを取付けた.また，ポンプの同一段には，それぞ れ 2 個の圧電素子を取付け，排水容積の増大を図っ た。通常, 圧電素子は，積瘄型とバイモルフ型に分類さ れるがここでは，ポンプ構造を簡略化するため，変 位拡大機楎なしでも大きな変位量が得られるバイモル フ型の圧電素子(直径 $\phi 12 \mathrm{~mm} \times$ 厚さ $0.4 \mathrm{~mm}$ ) を用い た.これら上下 2 個の圧電素子を $180^{\circ}$ の位相差で駆動 するとともに，各段の圧電素子に所定の位相差を与え ることにより，内部の液体は連続的に吐出する。さら に, 本ポンプでは, ポンプ室の内容積を圧電素子の変 位量に近づけるために，素子の表面に凸型のシリコン ゴムを取付け，上下のゴムの中央部が点接触する構造 を採用した。これにより，流路部は滑らかにつながり 洗浄しやすい粠造となる，また，压電素子が液体と接 触することによる素子の性能低下も防止できる．さら に，ゴムの表面にはフッ素樹脂製 (FEP)のフィルムを 貼り付け,ゴム同士の接着防止および疎水性の向上を 図った。

このように輈成したポンプを稓層化すれば中間の圧 電素子を 2 チャンネルで共有できるので, 多チャンネ ル化に対応しやすい微量液送ポンプを実現できる。

図 2 に, 今回試作した 2 種類のモデルのうちの一つ,
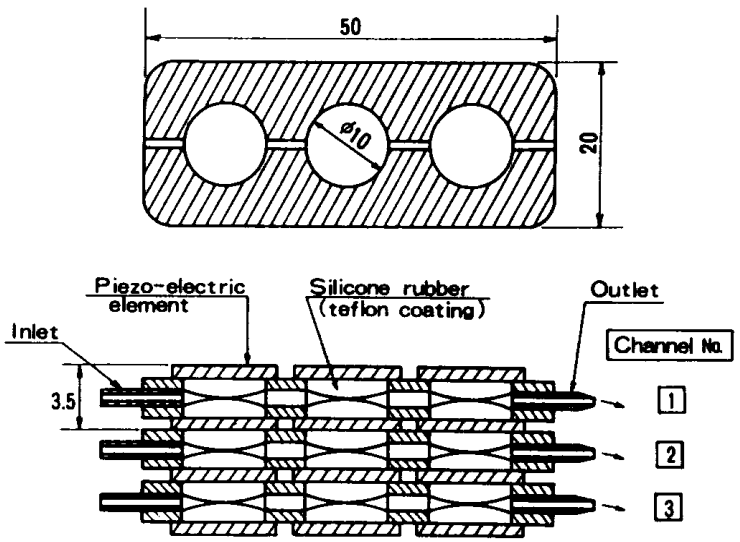

Stage No

2

3

図 1 压電素子応用微量液送ポンプの構造 (3段 3 連モデル)
3 段 1 連モデルの外観写真を示す. ポンプの上端およ び下端には，各 3 個の圧電素子(図中：十)を取付けて いる、ポンプの流れ方向は, 紙面の右から左方向であ り, 流出口の先端にノズルを取付けているようすがわ かる.

図 3 に本ポンプに供試したフロート式逆止弁の構造 を示す。これは, 内部に設けられたポリカーボネート 製のフロートの移動により流れを制御する方式の弁で ある.ポンプ全体の小型化を考虑し，逆止弁をポンプ の流路部に実装できる構造とした，本逆止弁は，順方 向の流れに対しては，フロートの後方に設けられたス リット部を通り液体は流出するが, 逆方向の流れには, 管内壁とフロート前方のテーパ部で流路を閉止する構 造である。ここで，テーパ部の先端角度は移動性を考 虑して $45^{\circ} に$ 設定した。この逆止弁をポンプの流入側 および流出側の 2 か所に取付けた。

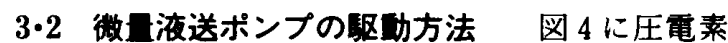
子の駆動制御方法を示す. 前述のように, 同一段の素 子は $180^{\circ}$ の位相差で駆動し，また，各段間の位相差は 1段めの素子を基準に駆動する，すなわち，2段めは 1 段めを基準に $\Delta \theta_{12}$ 遅らせ， 3 段めは 2 段めを基準に $\Delta \theta_{23}^{\circ}$ 遅らせるような位相制御を行う。これにより，ポ ンプ室内の水は, 流れの方向に治って連続的に吐出す る.

\section{4. 实験装置および方法}

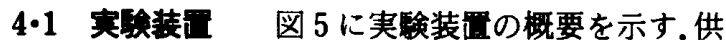

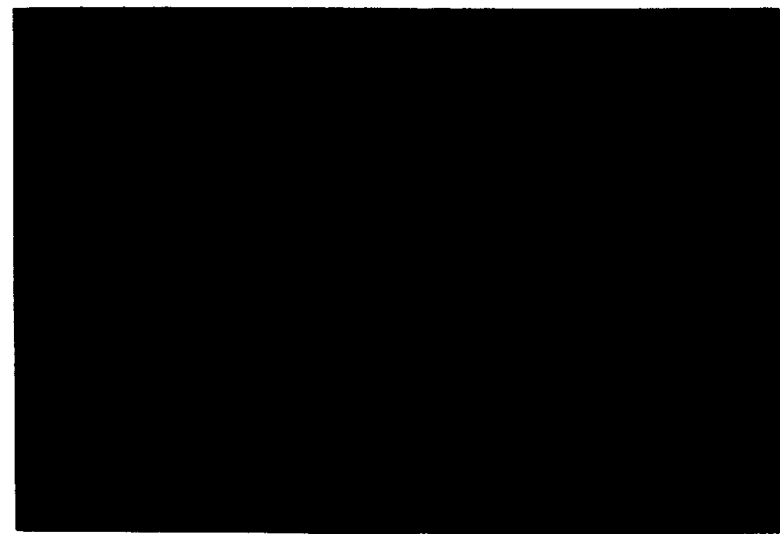

図 2 試作圧电ポンプの外覞 (3段 1 連モデル)
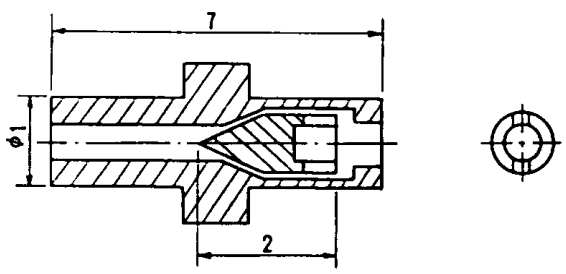

図 3 フロート式逆止弁の構造 
試ポンプの各圧電素子は压電索子駆動装置でそれぞれ 独立に駆動制御が可能である，表 1 に駆動装置の仕様 を示す. 出力波形はく形波で, 最大 $60 \mathrm{~V}$ の電圧を発生 することが可能である。ここで、素子の駆動波形をく 形波とした理由は，正弦波駆動と比較して，最大電圧 が印加されるまでの時間が短く，大流量化が図れるた めである，基準水位形成タンク内の液体はポンプで常 に循環され，タンク内部のせきでその水位を一定に保 つとともに，ポンプ中心と高さを合せるように構成し た。タンクから流出した液体は連続的に供試ポンプに 供給され，ポンプからの吐出量は重量計(電子天秤)で

表 1 圧電素子歌娌制御装置仕様

\begin{tabular}{|l|c|}
\hline Wave Shape & Ractangular \\
\hline Number of Channels & 10 \\
\hline Voltage (V) & $0 \sim 60$ \\
\hline Frequency (kHz) & $0 \sim 9.99$ \\
\hline $\begin{array}{l}\text { Phase } \\
\left.\text { Difference ( }{ }^{\circ}\right)\end{array}$ & $0 \sim 359$ \\
\hline
\end{tabular}
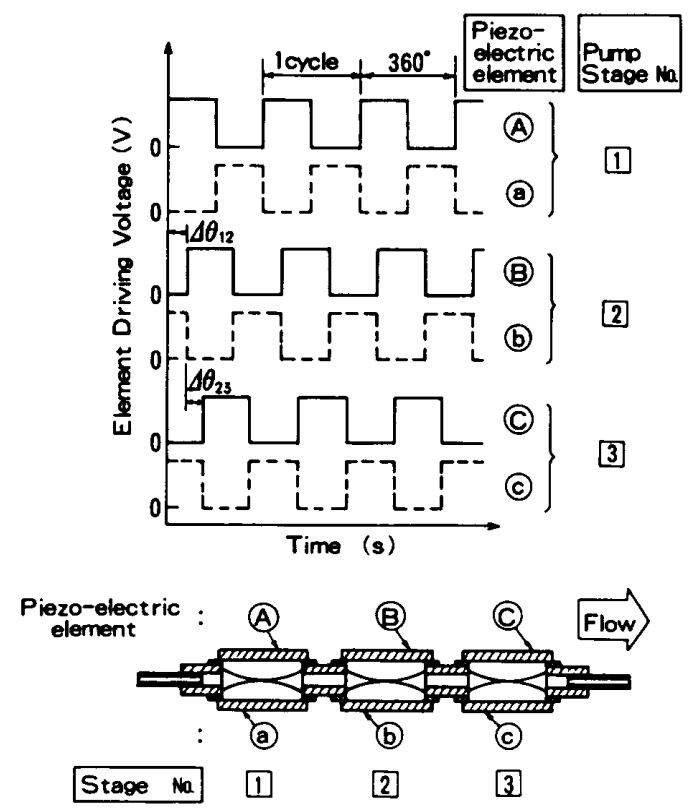

図 4 圧電素子の駆動制御方法

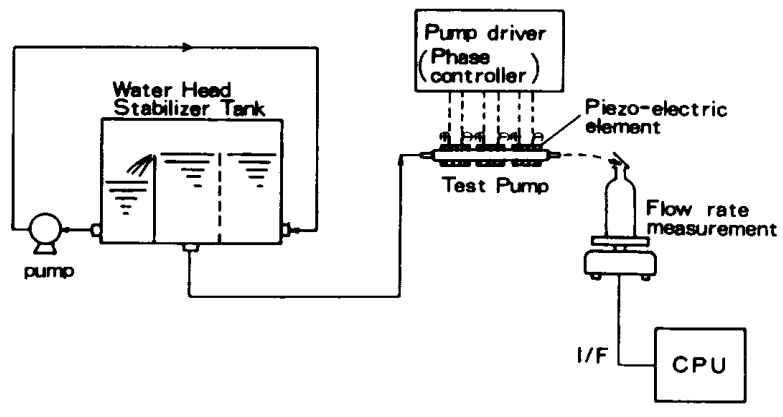

図 5 実験装置
測定し，結果をコンピュータに取込む方式とした。

4.2 实験方法 微量液送ポンプの基本特性とし て，流量および吐出圧に対する圧電素子の駆動周波数 および位相差の影䇾を検討した，ポンプの流量は重量 法で測定し， 2 分間の平均值で評価した。これは，時間 による変動量が比較的小さいことを考虑して定めた値 である.また，ポンプの吐出圧は，供試ポンプの吐出口 先端にフッ素樹脂製チューブを取付け，その液面の上 昇高さから求めた：この場合，タンクの水位とポンプ 流出口の中心高さを同一として，吸込み高さの影敏を 排除するとともに，事前に液面高さに与える表面張力 の影響の少ないことを確認している.なお，今回の実 験では，精製水を使用した。

\section{5. 实験結果およひ教察}

$5 \cdot 1$ ポンプ空の内部形状 微量液送ポンプの基 本特性実験に先立ち,ポンプ室内部の凸型ゴム形状に ついての基楚検討を行った，実験には，曲率半径の異 なる 3 種類のモデルを用いた。このうちの 2 種類は， 図 6 に示すように曲率半径 $R$ を変化させたもの，ま たもううつは，図示はしていないが $R=\infty$ としたモ デルである。ここで, 図6(a)のモデルは, 曲率半径を $25 \mathrm{~mm}$ として,ゴムの端部が流入出口の径と同一面 となるように設計したものである。これにより，式 (1)で定義される無次元平均ギャップ $G$ を 15 とし た。

$$
\begin{aligned}
& \text { 無次元平均 } \\
& \text { ギャップ } G \equiv \\
& \text { 上下のシリコンゴム間の平均ギャップ }
\end{aligned}
$$

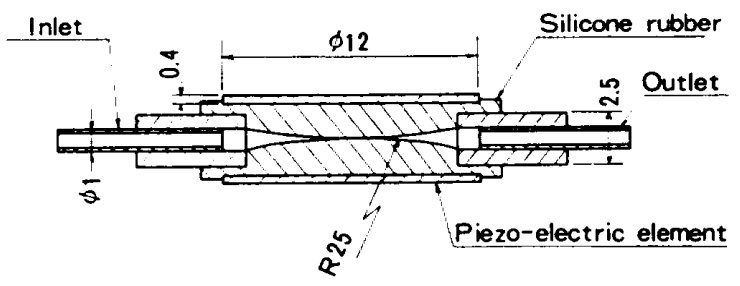

(a) Type A $(G=15)$

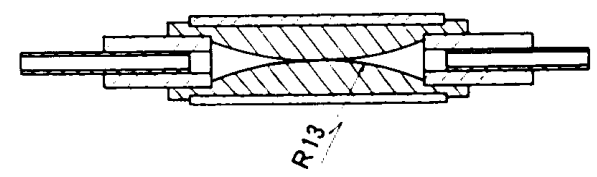

(b) Type B $(G=35)$

図 6 ポンプ室内部の凸型コム形状 
すなわち, 上下のシリコンゴム間の平均ギャップが压 電亲子の変位量 (電圧 $60 \mathrm{~V}$ 換算, 無負荷状態)の 15 倍 となる.一方, 図 6(b) のモデルは曲率半径を約 $1 / 2$ の $13 \mathrm{~mm}$ としたもので, この場合, 無次元平均ギャップ は $G=35$ となる。なお， $R=\infty$ モデルは曲率が $\infty$ ，す なわち, 平面としたもので $G=0$ となる.

表 2 に使用したシリコンゴムの仕様を示す．このゴ ムは，主に医療，食品用として使用されるもので，使 用温度範囲も - 55〜200 $\mathrm{C}$ と広いため, オートクレー ブなどの減菌処理にも耐えられ，生体試料用ポンプに 適用しても何ら問題がない。 また, 架橋密度が高く機 械的な衙䢂による塑性変形量が小さいので, 長時間使 用しても安定した微量液送を実現できる。

これらの凸型ゴムを単段 1 連モデルに取付け，圧電 索子の駆動周波数をパラメー夕にした予備実験を行っ た. その結果， $G=15$ タイプについては，広い周波数 領域で良好なポンプ性能を示した。しかし， $G=0$ 夕イ プは，ポンプとして作動しなかった。一方， $G=35$ 夕 イプは，ポンプとして作動はしたが，周波数 $100 \mathrm{~Hz}$ で $0.2 \mathrm{ml} / \mathrm{min}$ 程度の流量であり，他の領域では全く 吐出しなかった。これは，ポンプ室容積と圧電素子の 変位との相関関係にあると考える。すなわち, $G$ が小 さいと圧電素子の動きが封じられ， $G$ が大きいと十分 な圧力が発生しないためと考える。したがって，次節 以降で述べるポンプの基本特性は， $G=15$ タイプの凸 型コムを取付けた結果についてのみ説明する。

$5 \cdot 2$ 単段 1 連モデルの性能 図 7 に単段モデル の流量と圧電素子の駆動周波数の関係を示す。実験で は, 電圧 $60 \mathrm{~V}$ で圧電素子を駆動し，逆止弁の有無に よる性能比較を行った。その結果, 両者とも周波数の 高い領域で良好なポンプ性能を示した，逆止弁付きポ ンプの流量特性は，弁を取付けたことによる抵抗増加 のため, 運転領域は $100 \mathrm{~Hz}$ 程度狭くなるが, 流量に ついて見ると，周波数 $250 \mathrm{~Hz}$ 以下の全領域で 1.5 倍 程度增加し, 試作したフロート式逆止弁が有効に機能 していることがわかる．また，最大流量で比較すると， $0.7 \mathrm{ml} / \mathrm{min}$ から約 1.7 倍增の $1.2 \mathrm{ml} / \mathrm{min}$ の性能を 示した。

表 2 シリコンゴム仕様

\begin{tabular}{|l|c|}
\hline $\begin{array}{c}\text { Use in Medical } \\
\text { Production }\end{array}$ & Pasteurizaton \\
\hline Temperature (c) & $-55 \sim 200$ \\
\hline Specific Gravity & 1.07 \\
\hline Rubber Hardness & 20 \\
\hline
\end{tabular}

図 8 に逆止弁付き単段モデルの流量と圧電素子の駆 動里圧の関係を示す。ここでは，压電素子の駆動周波 数を $50,100,200 \mathrm{~Hz}$ の3通りとした。いすれれ周波 数においても，電圧と流量は直線関係にある。これは， 式（2）で表されるように，压電素子の変位量 $U$ が襇 動電圧 Vに比例するためであり，ポンプの流量を電 圧変化で調製可能なことを意味する。

$$
U=k \cdot d_{31} \cdot(D / t)^{2} \cdot V
$$

また，本ポンプでは，ノズル部での流出抵抗の影暒に より，駆動電圧が $25 \mathrm{~V}$ 以下の領域ではポンプ機能を もたない.

ここで，簡易的な理論モデルによるポンプ流量の算 出を試みる，まず，圧電素子の表面に取付けているシ リコンゴムの体㮴 $S$ は, 球冠の式で求めることがで きる。

$$
S=1 / 3 \cdot \pi \cdot h^{2} \cdot(3 r-h)
$$

この压電素子に一定の電圧を加えると，素子およびシ

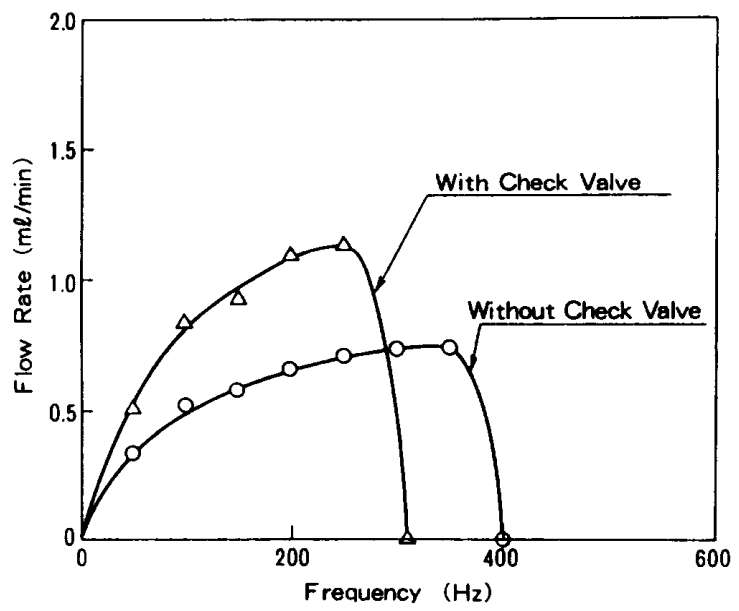

図 7 単段モデルの流量と周波数の関係

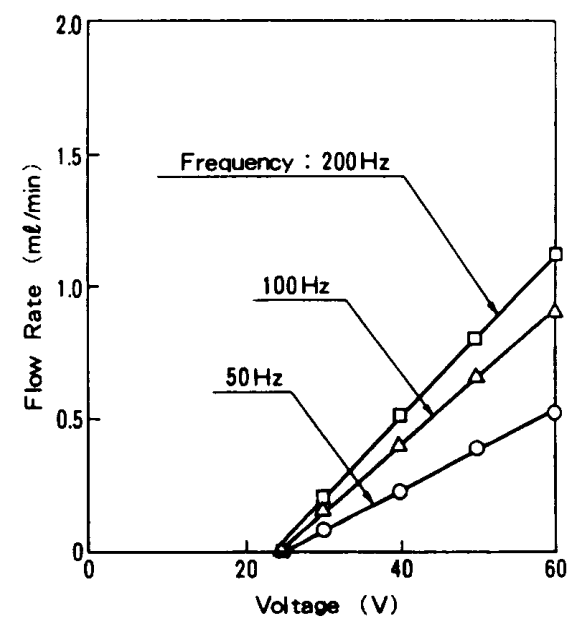

図 8 単段モデルの流量と電圧の関係 （逆止弁付き） 
リコンゴムは変形を生じ, ポンプ室内の液体量は増隇 する、ここで, ポンプ室の液体を排出する方向に圧電 素子を変形させた場合のシリコンゴムの体樌量 $S^{\prime}$ を 求める.ここで, 計算を简単にするため, ゴムが一様に 変形すると仮定すれば,

$$
S^{\prime}=1 / 3 \cdot \pi \cdot\left(h^{\prime}\right)^{2} \cdot\left(3 r^{\prime}-h^{\prime}\right)
$$

ここに, $h^{\prime}=h+U, r^{\prime}=r+U$ である.このシリコ ンゴムの体樌の差 $\left(S^{\prime}-S\right)$ が, 圧電素子が 1 回振動す るごとに排出される量である．压電素子の変位量につ いては, 前述した無負荷状態でかつ片持支持方式とし た場合, 供試圧電素子の変形量 $U$ は $16.6 \mu \mathrm{m}$ となる. しかし，本ポンプでは，素子全周を固定支持している ため, 変形量は大幅に隇少する。これを，簡易的にはり のモデルと仮定し, 変形量を求めると, 片持支持方式 の $1 / 5$ ，すなわち， $U=3.3 \mu \mathrm{m}$ となる.ここで, 本ポン プの侢造から, 圧電素子の変位量だけでは上下のシリ コンコム全体が密着することはないので, ポンプ室内 に流入した液体がすべて送出されることはなく，液体 の滞流係数をととすると，

$$
Q=\varepsilon \cdot n \cdot f \cdot\left(S^{\prime}-S\right) \cdot
$$

で表すことができる.

図 9 に, 圧電素子の駆動周波数と滞流係数 $\varepsilon$ の関係 を示す.図からもわかるように，ポンプに流入した液 の 1/4 以下しか送出されず, しかも周波数の增加に伴 い滞流係数 $は$ は低下する。これは，简易理論モデルて は流路部の管路抵抗について取扱っていないことお よび弾性体であるシリコンゴムの収縮率を考慮してい ないことなどが原因であると考える。

図 10 に単段モデルの吐出圧と圧電素子の駆動周波 数の関係を示す．図にも見るように，逆止弁なしでは 全領域で 0.2〜0.3 kPa 程度の吐出圧しかもたない. 一方, 逆止弁付きのポンプでは, 周波数が $50 \mathrm{~Hz}$ 以下 の領域では約 $9 \mathrm{kPa}$ の吐出圧をもち, 逆止弁による吐 出圧の向上効果を確認できた。しかし, 周波数が 100

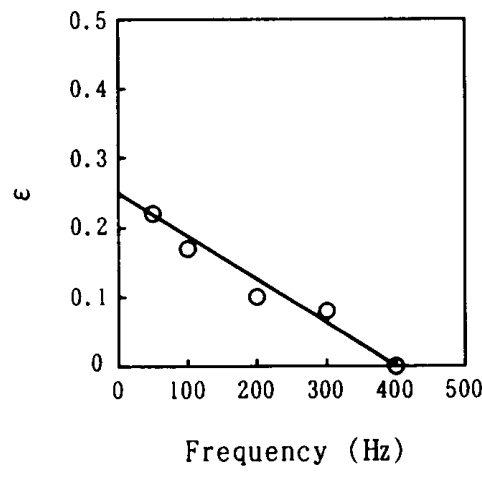

図 9 滞流係数と周波数の関係
$\mathrm{Hz}$ 以上の領域では，ほとんど吐出圧をもたないこと がわかった。この原因は，逆止弁内のフロートが液面 上昇量測定用チューブ内の水圧の影響を受け，フロー トの動きが圧電素子の駆動周波数に追従できなくなる からである. その結果, 両者の同期が取れず還流する 量が増加したものである。これにより，試作したフロ 一ト式逆止弁の最大吐出圧時における周波数応答性は $50 \mathrm{~Hz}$ 付近にあると推定する。

5 ·3 3 段1遧モデルの性能 図11に逆止弁なし 3 段モデルの流量と駆動周波数の関係を示す。ここで は，ポンプ各段間の位相差をパラメータとし，1-2段 めの位相差 $\Delta \theta_{12}$ と, 2-3 段めの位相差 $\Delta \theta_{23}$ を同じ值 に設定して実験を行った。 その結果, 位相差を大きく 与えるほど流量が增加するとともに，高い周波数領域 でもポンプ機能をもつことがわかった。このうち，位

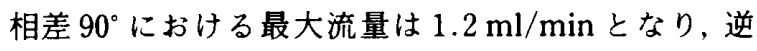
止弁付き単段モデルと同等の流量を示した。しかし， 高周波数で駆動した場合，ポンプの脈動低減には有効 であるが, 一方では素子の振動音増加や低寿命化につ

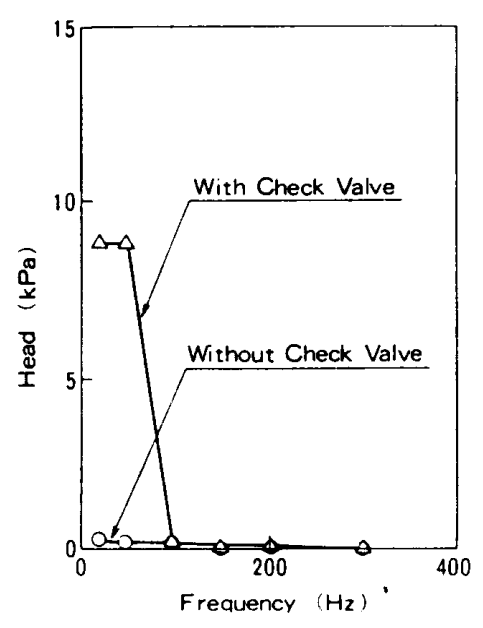

図 10 単段モデルの吐出圧

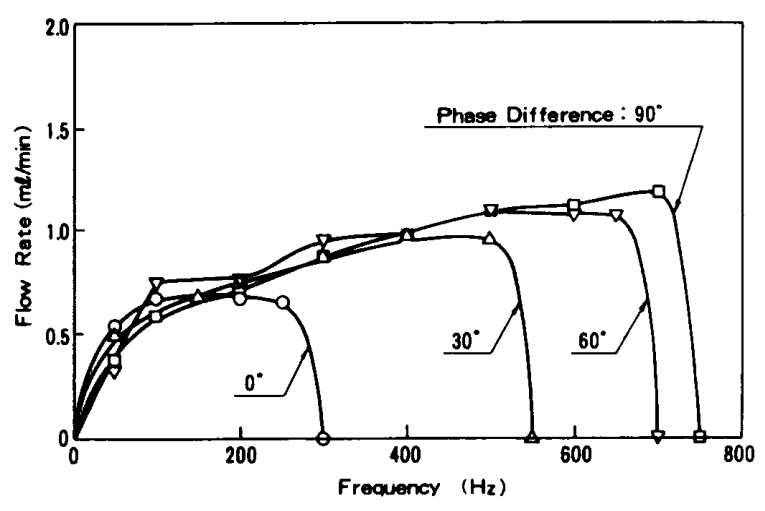

図 113 段モデルの流量と周波数の関係 (逆止弁なし) 


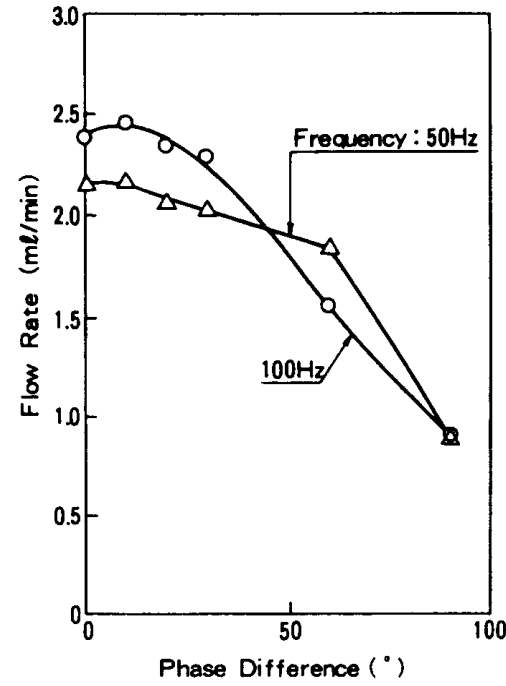

困 123 段モデルの流量と段間位相差 の関係(逆止弁付き)
ながること、またポンプの構成要素であるシリコンゴ ムや逆止弁などの応答性も考虑すると，低脈動を保持 できる範囲で低い周波数で駆動することが好ましく， コストを考慮すると電源周波数の 50 〜 $60 \mathrm{~Hz}$ が望ま Lᄂ.

図 12 に逆止弁付き 3 段モデルの流量とポンプ各段 間位相差の関係を示す。ここでは，周波数を 50,100 $\mathrm{Hz}$ の低領域に設定し実験を行った、いずれの場合も， 位相差 $10^{\circ}$ でわずかなピークをもつが，全体的には位 相差が増加すると流量は低下する傾向をもつ，しかし， 流量の絶対值は，単段モデルと比較して大幅に増加し ている。例えば, 周波数 $100 \mathrm{~Hz}$ における最大流量は約 2 倍の $2.5 \mathrm{ml} / \mathrm{min}$ となり，ポンプの多段化は流量の 増加にも有効であることがわかった。

図 13 に逆止弁付き 3 段モデルの $Q-H$ 特性を示す. ポンプの吐出圧は, 圧電素子の駆動周波数が小さいほ ど良好な性能を示し, 周波数 $10 \mathrm{~Hz}$ における最大吐出 圧は $18 \mathrm{kPa}$ となる。この值は, 単段モデルの約 2 倍に 相当し、ポンプの多段化による吐出压向上の効果を確 認することができた。なお，ポンプの昍出圧は、ポンプ の各段間にも逆止弁を設けることで，さらに向上可能 と考える。

これら 3 段 1 連モデルの実験結果から,ポンプの多

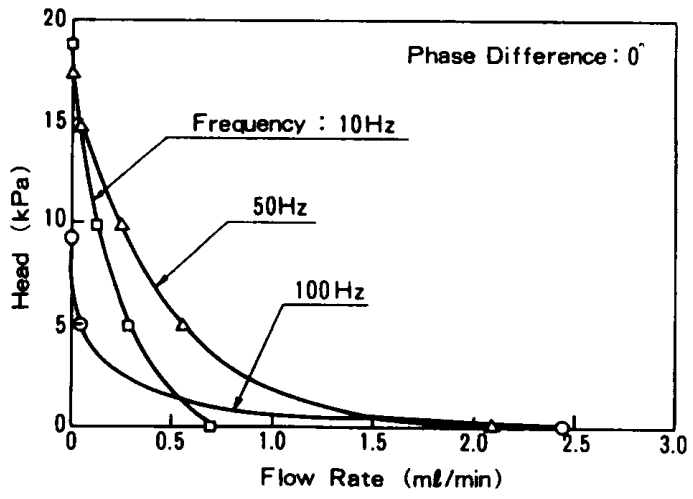

図 13 3段モデルの $Q-H$ 特性(逆止弁付き)

段桠造は，ほほ同位相で駆動制御することにより，当 初予想した吐出圧向上に加え, 流量の增加にも有効で あることがわかった。

\section{6. 結}

多チャンネル化に対応しやすく, 連続低脈動供給が 可能なポンプとして, 圧電素子を応用した微量液送ポ ンプを開発し，試作した 2 種類のモデルを用いて，そ の基本特性を実験的に検討した結果を以下に要約す る.

（1）ポンプ室内部の凸型ゴム形状は，ポンプ性能 発揮のポイントであり，試作した形状の中では，上下 のゴム間の平均ギャップを压電素子の変位量の 15 倍 としたものが良好な性能をもつ。

（2）ポンプの多段化は, 流量および吐出圧の増加 に有効であり，3段 1 連モデルは，単段 1 連モデルの 約 2 倍の性能をもつ.

（3） 3 段 1 連モデルは，各段間を同位相で駆動制 御することにより, 最大流量 $2.5 \mathrm{ml} / \mathrm{min}$, 最大吐出圧 $18 \mathrm{kPa}$ の性能を示す。

（4）ポンプの流量は, 圧電素子の駆動電圧と一次 関数であるため，電圧変化による流量調整が適する。

\section{女 献}

（1）内山・ほか 3 名, 分析化学, 36-1，(1987)，54.

（2）小島・ほか 3 名, 機講論, Vol. 62 C, (1991)，580.

（3）江刺, 応用物理，60-3，(1991)，227.

(4) MIYAZAKI, S., は 2名, IEEE-MEMS Workshop, (1991), 283 